\title{
Proposal to Conserve the Specific Epithet liquefaciens Over the Specific Epithet proteamaculans in the Name of the Organism Currently Known as Serratia liquefaciens (Grimes and Hennerty 1931) Bascomb et al. 1971
}

\author{
Request for an Opinion
}

\author{
B. HOLMES \\ National Collection of Type Cultures, Central Public Health Laboratory, Colindale, London NW9 5HT, \\ United Kingdom
}

\begin{abstract}
It is proposed that the Judicial Commission of the International Committee on Systematic Bacteriology conserve the specific epithet liquefaciens over the specific epithet proteamaculans in the scientific name of the organism currently known as Serratia liquefaciens (Grimes and Hennerty 1931) Bascomb et al. 1971. Although the name Pseudomonas proteamaculans was applied to what may be the same organism and was validly published by Paine and Stansfield in 1919, the name remained obscure until the only extant strain, claimed to originate from the collection on which Paine and Stansfield based their description of P. proteamaculans, was found by Grimont et al. in 1978 to be identical with $S$. liquefaciens biotype C1c. Meanwhile, the name Serratia liquefaciens has gained worldwide acceptance. To stabilize the nomenclature and to avoid confusion in the literature, the specific epithet liquefaciens should be retained in the name of this organism.
\end{abstract}

Grimes and Hennerty in 1931 (9) described an organism to which they gave the name Aerobacter liquefaciens. A. liquefaciens was later transferred to the genus Enterobacter as $E$. liquefaciens by Ewing in 1963 (6), and the species was in turn transferred to the genus Serratia by Bascomb et al. in 1971 (2). The transfer of $E$. liquefaciens to the genus Serratia (2) was supported by Ewing et al. (7), who designated ATCC 27592 as the type strain of the species, and the transfer has been further supported by the results of a numerical taxonomy study (10) and of a polynucleotide sequence relatedness study (17). Despite the combination with three different generic names, the specific epithet $l i$ quefaciens has remained unchanged, and the more recent transfer from Enterobacter to Serratia (2) has been well documented and generally accepted. Serratia marcescens, the type species of the genus, although once dismissed as a saprophyte, has emerged in recent years as a significant human pathogen (3). S. liquefaciens, whose clinical significance is doubtful, shows a close similarity to $S$. marcescens in biochemical tests, and consequently $S$. liquefaciens has become widely known to clinical bacteriologists who frequently wish to differentiate between $S$. liquefaciens and S. marcescens when identifying an unknown strain. The long period of stability in the usage of the specific epithet liquefaciens has been brought to an end after the recommendation by Grimont et al. (11) to replace the specific epithet liquefaciens in the name Serratia liquefaciens (Grimes and Hennerty) Bascomb et al. 1971 by the specific epithet proteamaculans.

In 1919, Paine and Stansfield (16) described the species Pseudomonas proteamaculans. The organism was placed at various times in the genera Xanthomonas, Erwinia, and Enterobacter and is listed in the first draft (1) of the "Approved Lists of Bacterial Names" as Er. winia proteamaculans (Paine and Stansfield 1919) Dye 1966. The only extant strain of $E r$ winia proteamaculans (ATCC 19323 = Dye ZL1 $=$ ICPB XP176 = NCPPB 245) was claimed by Grimont et al. (11) to originate from the collection on which Paine and Stansfield based their description of $P$. proteamaculans; Grimont et al. (11) consequently designated this strain as the type strain of the species. Grimont et al. (11) clearly demonstrated that ICPB XP176 corresponds to Serratia liquefaciens biotype C1c. Fifty phenotypic characteristics were determined for NCPPB 245 in the NCTC, and the results of these tests in conjunction with a probability matrix held in a computer confirmed that this strain indeed corresponds to S. liquefaciens. Because of the principle of priority (15), Grimont et al. (11) were faced with two alternative nomenclatural positions: either (i) to recommend replacement of the specific epithet liquefaciens in the name Serratia liquefaciens (Grimes and Hennerty 1931) Bascomb et al. 1971 by the 
specific epithet proteamaculans; or (ii) to request the Judicial Commission of the International Committee on Systematic Bacteriology to allow conservation of the specific epithet lique. faciens in the "well-known name Serratia lique. faciens." Grimont et al. (11) favored the former approach and formally proposed that the specific epithet proteamaculans replace the epithet liquefaciens in $S$. liquefaciens. This proposal also results in a change of the type strain of the species, the type strain of $S$. liquefaciens (ATCC 27592) being replaced by the type strain of $S$. proteamaculans (ICPB XP176 = ATCC 19323).

Although ATCC 27592 is referred to above as the type strain of $S$. liquefaciens, there is some confusion on this point in the literature, since Grimont et al. $(10,11)$ consider ATCC 14460 to be the type strain of $S$. liquefaciens. In the original description of Aerobacter liquefaciens (9), culture $K$ was designated the type species (sic), and culture G was the only other strain ascribed to the species. Although cultures from M. Grimes, one of the authors of the original description of Aerobacter liquefaciens (9), were deposited in culture collections (ATCC $14460=$ NCIB 9321; ATCC 14461 = NCIB 9322; ATCC 27592), none of these strains is known to correspond to either culture $K$ or to culture G (R. L. Gherna and I. Bousfield, personal communications). Grimes is known to have indicated in personal correspondence to R. E. Buchanan (7, 10) that ATCC 14460 was the type strain of Aerobacter lipolyticus (syn.: Serratia liquefaciens), but Grimes never formally designated it the type strain. Of the extant strains from Grimes, ATCC 27592 was selected and designated the type strain of $S$. liquefaciens (7). None of the three strains from Grimes could be proved to be strains on which the original description of Aerobacter liquefaciens (9) was based, so the strain selected by Ewing et al. (7), ATCC 27592, should have been proposed as the neotype strain of $S$. liquefaciens and should not have been designated the type strain. Despite not adhering strictly to the International Code of Nomenclature of Bacteria and Viruses (13), Ewing et al. (7) did at least make a formal designation of a type strain for S. liquefaciens. ATCC 27592 should thus be regarded as the type strain of $S$. liquefaciens, and Grimont et al. $(10,11)$ are incorrect in considering ATCC 14460 to be the type strain of the species when it has never been formally proposed as such.

In justifying their proposal that the specific epithet proteamaculans replace the epithet $l i$. quefaciens in S. liquefaciens, Grimont et al. (11) stated that conservation is often requested when an earlier synonym is poorly known and is not represented by an authentic culture. They (11) admitted that the name Pseudomonas protea- maculans is probably unknown to most clinical bacteriologists, but stated that the species had been included in some taxonomic studies carried out by plant bacteriologists. Grimont et al. (11) also pointed out that a single "authentic" strain of Erwinia proteamaculans is extant.

It is here proposed that the specific epithet liquefaciens be conserved over the specific epithet proteamaculans on the basis of the following considerations. The name Serratia liquefaciens is well known, and Grimont et al. (11) admit that this is the case. It seems likely that more bacteriologists than not work in the clinical field and that most clinical bacteriologists are familiar with the specific epithet liquefaciens by the consistent use of this epithet, as in Enterobacter liquefaciens, in medical journals and textbooks from 1963 (6) to 1971 , at which time the species became known as Serratia liquefa. ciens (2). The epithet liquefaciens has thus been stable in the name of this organism for many years until the recent proposal by Grimont et al. (11). The latter authors (11) admit that the name Pseudomonas proteamaculans is probably unknown to most clinical bacteriologists. It seems likely that only a relatively small proportion of bacteriologists are plant bacteriologists, and there is little evidence that many of these will be familiar with the name Pseudomonas proteamaculans. Grimont et al. (11) state that the species has been included by plant bacteriologists in several taxonomic studies $(4,5,12$, $18)$, but for three of these studies at least $(4,5$, 12 ), only a single strain of the species was examined, and in each case it was the same strain (Dye ZL1 = PDDCC $1724=$ NCPPB $245=$ ICPB XP176), the strain proposed by Grimont et al. (11) as the type strain of the species. There is thus no evidence in the literature that the species name Pseudomonas proteamaculans (with different generic names) has been applied to any strain other than ICPB XP176 (ATCC 19323). This suggests that plant bacteriologists have rarely, if ever, encountered additional strains which they would call $P$. proteamaculans so that those plant bacteriologists who are aware of this species name are aware only through the existence of the single strain ICPB XP176 (= ATCC 19323). Grimont et al. (11) claim that ICPB XP176 is authentic and originates from the collection on which Paine and Stansfield based their description of $P$. proteamaculans. However, since no strain numbers are given in the original description of $P$. proteamaculans (16), whereas ICPB XP176 certainly was a strain of one of the authors of the species (confirmed by NCTC records on NCTC 394, a strain no longer maintained in the NCTC but from which ICPB XP176 is derived), it cannot be proved to be a strain on which the original 
description of the species was based. Accordingly, ICPB XP176 should perhaps have been more properly proposed as the neotype of the species. Examination of NCPPB 245 in the NCTC confirms that it is gram-negative, motile, and peritrichous and thus differs from the original description of the species (16), wherein $P$. proteamaculans is stated to be gram-positive and motile by means of one to three polar flagella. Whether the original description of the species was incorrect or there has been some error during the maintenance of the culture in the NCTC or NCPPB is purely speculation; the fact remains that NCPPB 245 does not conform to the original description of Pseudomonas proteamaculans (16).

In a similar plea for nomenclatural stability, Farmer et al. (8) justified their request for conservation of the specific epithet tarda over the specific epithet anguillimortiferum in the name of the organism presently known as Edwardsiella tarda by citing principle 1 of the International Code of Nomenclature of Bacteria and Viruses (13): "The essential points in nomenclature are (1) to aim at fixity of names; (2) to avoid or to reject the use of names which may cause error or ambiguity or throw science into confusion." This principle is reiterated in the most recent version of the International Code of Nomenclature of Bacteria (15). Clearly, acceptance of the epithet proteamaculans would violate the intent of principle 1 quoted above, and the stability of nomenclature would best be served by conserving the specific epithet liquefaciens over the specific epithet proteamaculans.

Farmer et al. (8) also pointed out that in opinion 18 (14) the Judicial Commission of the International Committee on Bacteriological Nomenclature conserved typhi over typhosa as the specific epithet for the causative organism of typhoid despite the priority of typhosa over typhi. The Judicial Commission, in issuing its opinion, cited principle 1 of the International Code of Nomenclature of Bacteria and Viruses (13). Their decision (14) was based upon the more common usage of the epithet typhi as compared with that of the epithet typhosa. In the opinion (14), it was stated that "acceptance of typhi rather than typhosa was desirable in order to minimize confusion in the literature."

In consideration of the foregoing, in the interest of stability in nomenclature, and to avoid confusion in the literature, it is requested that the Judicial Commission of the International Committee on Systematic Bacteriology issue an opinion conserving the specific epithet liquefaciens over proteamaculans in the scientific name Serratia liquefaciens (Grimes and Hennerty 1931) Bascomb et al. 1971. The type strain would remain ATCC 27592.
Bascomb et al. 1971. The type strain would remain ATCC 27592.

\section{REPRINT REQUESTS}

Reprints are not available

\section{LITERATURE CITED}

1. Ad-Hoc Committee of the Judicial Commission of the ICSB. 1976. First draft. Approved lists of bacterial names. Int. J. Syst. Bacteriol. 26:563-599.

2. Bascomb, S., S. P. Lapage, W. R. Willcox, and M. A. Curtis. 1971. Numerical classification of the tribe Kleb. sielleae. J. Gen. Microbiol. 66:279-295.

3. Brooks, H. J. L., T. J. Chambers, and S. Tabaqchali. 1979. The increasing isolation of Serratia species from clinical specimens. J. Hyg. 82:31-40.

4. Dye, D. W. 1966. A comparative study of some atypical "xanthomonads." N. Z. J. Sci. 9:843-854.

5. Dye, D. W. 1969. A taxonomic study of the genus Erwinia. IV. "Atypical" erwinias. N. Z. J. Sci. 12:833-839.

6. Ewing, W. H. 1963. An outline of nomenclature for the family Enterobacteriaceae. Int. Bull. Bacteriol. Nomencl. Taxon. 13:95-110.

7. Ewing, W. H., B. R. Davis, M. A. Fife, and E. F. Lessel. 1973. Biochemical characterization of Serratia liquefaciens (Grimes and Hennerty) Bascomb et al (formerly Enterobacter liquefaciens) and Serratia rub idaea (Stapp) comb. nov. and designation of type and neotype strains. Int. J. Syst. Bacteriol. 23:217-225.

8. Farmer, J. J., III, D. J. Brenner, and W. A. Clark. 1976. Proposal to conserve the specific epithet tarda over the specific epithet anguillimortiferum in the name of the organism presently known as Edwardsiella tarda. Int. J. Syst. Bacteriol. 26:293-294.

9. Grimes, M., and A. J. Hennerty. 1931. A study of bacteria belonging to the sub-genus Aerobacter. Sci. Proc. R. Dublin Soc. (N.S.) 20:89-97.

10. Grimont, P. A. D., F. Grimont, H. L. C. Dulong de Rosnay, and P. H. A. Sneath. 1977. Taxonomy of the genus Serratia. J. Gen. Microbiol. 98:39-66.

11. Grimont, P. A. D., F. Grimont, and M. P. Starr. 1978 Serratia proteamaculans (Paine and Stansfield) comb. nov., a senior subjective synonym of Serratia liquefa. ciens (Grimes and Hennerty) Bascomb et al. Int. J. Syst. Bacteriol. 28:503-510.

12. Imbs, M. A., R. Bene, T. Girard, C. Goulon, and P. Dixneuf. 1977. Taxonomie numérique des bactéries du genre Erwinia. Microbia 3:3-34.

13. International Committee on Bacteriological Nomenclature (ed.). 1958. International code of nomenclature of bacteria and viruses. Iowa State College Press, Ames.

14. International Committee on Bacteriological Nomenclature. Judicial Commission. 1963. Opinion 18. Conservation of typhi in the binary combination Salmonella typhi. Int. Bull. Bacteriol. Nomencl. Taxon. 13:31-33.

15. Lapage, S. P., P. H. A. Sneath, E. F. Lessel, V. B. D. Skerman, H. P. R. Seeliger, and W. A. Clark (ed). 1975. International code of nomenclature of bacteria. American Society for Microbiology, Washington, D.C.

16. Paine, S. G., and H. Stansfield. 1919. Studies in bacteriosis. III. A bacterial leaf-spot disease of Protea cynaroides, exhibiting a host reaction of possibly bacteriolytic nature. Ann. Appl. Biol. 6:27-39.

17. Steigerwalt, A. G., G. R. Fanning, M. A. Fife-Asbury, and D. J. Brenner. 1976. DNA relatedness among species of Enterobacter and Serratia. Can. J. Microbiol. 22:121-137.

18. -St. John-Brooks, R., K. Nain, and M. Rhodes. 1925. The investigation of phytopathogenic bacteria by serological and biochemical methods. J. Pathol. Bacteriol. 28:203-209. 